\title{
PRAKTEK JUAL BELI BAHAN BANGUNAN DENGAN SISTEM WAKALAH
}

\author{
Bahmid I Magi \\ Universitas Ma'soem, Indonesia \\ magimid@gmail.com
}

\begin{tabular}{l}
\hline Informasi artikel \\
\hline Kata kunci: \\
Jual Beli \\
Bahan Bangunan \\
Wakalah
\end{tabular}

Keywords:

Buying and Selling Building Materials Wakalah

\begin{abstract}
ABSTRAK
Manusia menjalankan kehidupan selalu membutuhkan orang lain. Aktivitas seperti jual beli sangat memerlukan bantuan agar segalanya bisa terselesaikan. Wakalah sebagai bentuk transaksi yang mewakilkan orang lain, mengalami perubahan-perubahan karena kondisi zaman. Seperti seorang yang meminta pembuat bangunan untuk mewakilkan penyelesaikan pembangunan rumahnya. Transparansi harga yang tidak jelas dalam traksaksi menjadi persoalan dalam penelitian ini. Tujuannya menganalisis jual beli wakalah ini agar sesuai dengan ketentuan akad dan hukum ekonomi syariah. Metode penelitian adalah fielt resech, yaitu menelaah kasus yang terjadi kemudian dianalisis berdasarkan literatur dan hukum Islam. Akad jual beli wakalah yang terjadi menjadi batal karena tidak memenuhi rukun dan syarat berupa ketidakjujuran dan tidak ada transparansi harga dari orang yang diwakilkan.
\end{abstract}

\section{ABSTRACT}

The practice of buying and selling building materials with the wakalah system. Humans run their lives always need other people. Jobs such as buying and selling really need help so that everything can be resolved. Wakalah as a form of transaction that represents other people, undergoes changes due to the conditions of the times. Like someone who asks a builder to represent the completion of the construction of his house. Unclear price transparency in transactions is a problem in this research. The aim is to analyze the sale and purchase of this wakalah so that it is in accordance with the provisions of the contract and sharia economic law. The research method is field research, which is examining cases that occur and then being analyzed based on Islamic literature and law. The wakalah sale and purchase contract that occurred was canceled because it did not meet the pillars and conditions in the form of dishonesty and no price transparency from the person represented.

Copyright (O) 2022 (Bahmid I Magi). DOI: https://doi.org/10.52593/mtq.03.1.03 Naskah diterima: 29 Desember 2021, direvisi: 30 Desember 2021, disetujui: 29 Januari 2022

\section{A. Pendahuluan}

Manusia pada umumnya dilahirkan seorang diri. Meski demikian, hidupnya selalu bermasyarakat, karena Allah Swt telah menjadikan manusia sebagai makhluk sosial yang selalu membutuhkan orang lain agar bisa tolong-menolong, tukar menukar, jual beli, sewa-menyewa, demi kemaslahatan dan kepentingan bersama. Keterangan di atas menjadi indikator bahwa manusia sebagai mahkluk sosial yang selalu beriteraksi dengan 
makhluk lainnya untuk memenuhi kebutuhannya dan selalu memerlukan orang lain sebagai wakilnya.

Urusan bermuamalah dilarang apabila terdapat unsur yang mengandung penindasan, pemerasan atau penganiyaan terhadap orang lain, semisal jual beli tersebut mengandung unsur penipuan dan merugikan orang lain karena pada dasaranya, dalam permasalahan muamalah banyak terjadi spekulasi transaksi dimana hal tersebut bertujuan mengambil manfaat dari transaksi dengan cara yang tidak dibenarkan di dalam Islam.

Dalam kehidupan masyarakat, manusia tidak dapat hidup sendiri dan pasti membutuhkan bantuan orang lain. Oleh karena itu, didalam Islam jual beli yang dilakukan dengan perantara orang lain yang diatur melalui metode wakalah, yaitu menyerahkan pekerjaan yang dikerjakan kepada orang lain. Namun, pekerjaan saling tolong menolong antara sesama manusia tersebut tidak jarang terdapat perselisihan. Kita sering sekali berselisih dengan orang lain dalam berbagai masalah. Perselisihan tersebut bisa bersifat kecil bahkan besar.

Islam telah mengajarkan kita untuk mengadakan sebuah perjanjian atau penyelesaian masalah tersebut dengan mengadakan perdamaian. Sulbu atau perdamaian sangatlah penting agar manusia dapat berdampingan secara harmonis. Adapun akad wakalah mempunyai landasan hukum, syarat maupun rukun dalam pelaksanaannya. Dari dahulu hingga sekarang, masyarakat membutuhkan akad wakalah untuk menyelesaikan segala persoalan hidup mereka. Hal ini terjadi karena unsur keterbatasan yang senantiasa melingkupi kehidupan manusia. Untuk itu, syariah memberikan legalitas atas keabsahan akad tersebut.

Akad wakalah sebagai bentuk transaksi yang diwakilkan kepada orang lain bisa menjadi solusi bagi setiap orang yang mempunyai keterbatasan waktu dalam melaksanakan transaksi ekonomi. Keterbatasan itulah yang menyebabkan transaksi itu harus diserahkan kepada orang lain untuk melakukannya. Hal ini menunjukan bahwa manusia tidak 
bisa hidup sendiri seperti yang dikatakan oleh Aristoteles bahwa manusia sebagai zoon politicon (manusia tidak bisa hidup sendiri dan selalu membutuhkan orang lain).

Dalam banyak riwayat yang tepercaya, diceritakan bahwa Rasulullah mewakilkan pembayaran utang, mewakilkan penetapan budud dan pembayarannya, mewakilkan pemeliharaan unta, kandang dan kulitnya, serta mewakilkan hal-hal lain. Umat Islam telah bersepakat tentang diperbolehkannya wakalah, bahkan mereka menganjurkan karena itu termasuk bagian dari ta'awun (tolong-menolong) atas dasar kebaikan dan taqwa.

Jika seorang wakil terikat maka si wakil berkewajiban mengikuti apa saja yang telah ditentukan oleh orang yang mewakilkan, ia tidak boleh menyalahi, kecuali kepada yang lebih baik buat orang yang mewakilkan, jika ia ditentukan dengan harga tertentu, kemudian ia menjual dengan harga yang lebih tinggi maka penjualan tersebut sah karena memberikan kebaikan bagi orang yang mewakilkan.

Kasus yang terjadi pada pemborong dan juga penjual barang bangunan yang melakukan transaksi jual beli dimana terjadi perubahan harga pada kwitansi dibuat oleh toko bangunan berdasarkan permintaan dari pemborong. Misalnya harga yang ditawakan Rp. 25.000 rupiah pada item tertentu, namun dalam kwitansi pembayaran bisa terjadi perubahan menjadi Rp. 30.000 rupiah atas permintaan pemborong agar mendapatkan keuntungan. Kasus seperti ini banyak terjadi di masyarakat. Karena proyek pembangunan yang sudah diserahkan secara keseluruhan kepada pemborong, namun bahan baku masih menjadi tanggung jawab dari pemilik rumah.

Kegiatan pembangun di masyarakat bentuk pengerjaannya berbeda-beda. pertama: menyerahkan seluruh pekerjaan kepada pemborong dengan perhitungan estimasi sampai selesai. Kedua: pekerjaan tidak secara keseluruhan diberikan kepada kepada pemborong, namun hanya pekerja harian yang sesuai dengan kesepakatan.

Kedua model pekerjaan itu, memberi ruang yang sangat terbuka bagi para pekerja/ pemberong yang diwakilkan untuk membelanjakan bahan bangunan yang diperlukan. 
Namun, terjadi penyelewengan harga yang terjadi ketika mereka ingin mendapatkan yang lebih dari selisih harga yang sudah direncanakan dengan menaikan harga dari yang sebenarnya. Kasus-kasus seperti ini banyak terjadi di masyarakat sehingga, penulis ingin meneliti persoalan dengan judul: Praktek jual beli bahan bangunan dengan sistem wakalah. Penelitian ini berupa Studi Kasus di Toko Bangunan HL. Putra 2, kabupaten Bandung.

\section{B. Teori / Konsep}

\section{Pengertian Akad}

Menurut Bahasa (Hendi Suhendi, 2016) 'Aqad mempunyai beberapa arti, antara lain:

a. Mengikat (الربط الرب), yaitu:



"Mengumpulkan dua ujung tali dan mengikat salah satunya dengan yang lain sehingga bersambung, kemudian keduanya menjadi sebagai sepotong benda."

b. Sambungan (عقدة), yaitu:

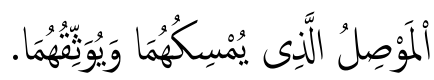

"Sambungan yang memegang kedua ujung itu dan mengikatnya"

c. Janji (العهد) sebagaimana diperjelas dalam Al-Qur'an :



“(Bukan demikian), sebenarnya siapa yang menepati janji (yang dibuat)nya dan bertakwa, maka sesungguhnya Allah menyukai orang-orang yang bertakwa." (QS. Ali Imran: 76).

Shalah Ash-Shawi dan Abdullah Al-Mushlih (2014) mendefinisikan tentang akad, bahwa secara bahasa ialah akad atau perjanjian itu digunakan untuk banyak arti, yang keseluruhannya kembali kepada bentuk ikatan atau penghubungan terhadap dua hal. Sementara akad menurut istilah adalah keterikatan keinginan diri dengan sesuatu yang lain dengan cara yang memunculkan adanya komitmen tertentu yang disyariatkan. 
Istilah "perjanjian" dalam hukum Indonesia sedangkan "aqad" dalam hukum Islam. Ada beberapa definisi yang diberikan kepada akad (perjanjian):

a. Akad merupakan pertemuan ijab yang diajukan oleh salah satu pihak dengan kabul dari pihak lain yang menimbulkan akibat hukum pada objek akad.

b. Menurut penulis, akad adalah pertemuan ijab dan kabul sebagai pernyataan kehendak dua pihak atau lebih untuk melahirkan suatu akibat hukum pada objeknya.

\section{Kerja Sama dalam Islam}

Kerja sama sangat dianjurkan oleh setiap manusia, sehingga manusia selalu diidentikan dengan makhluk yang tidak bisa hidup sendiri tanpa bantuan orang lain. Dalam kajian ekonomi Islam akad-akad yang dibahas juga merupakan bagian kerja sama yang tidak lepas dari kehidupan manusia. Al-Qur'an dan hadits menggambarkan bahwa kerja sama sangat dianjurkan, seperti dalam hadits qudsi yang menjelaskan tentang keikutsertaan Allah diantara dua orang melakukan kerja sama. Seperti Sabda Nabi yang artinya "Saya (Allah) adalah yang ketiga dari dua orang yang menjalin kerjasama selama tidak saling berkhianat terhadap temannya. Ketika salah satu diantaranya ada yang berkhianat terhadap temannya, maka Saya (Allah) keluar darinya".

Inti dari hadits ini adalah Allah menjadi orang ketiga yang ada diantara dua orang yang bertransaksi dan memberikan pertolongan terhadap keduanya, menjaganya, memberikan berkah terhadap hartanya selama tidak ada khianat. Jika terjadi hal yang tidak sesuai dengan perjanjian maka pertolongan Allah akan diangkat darinya.

Dorongan untuk kerja sama yang dianjurkan pada hadits diatas karena ada jaminan yang Allah berikan berupa kerja sama, pertolongan, penjagaan dan keberkahan dalam setiap usaha yang dijalankan. Selain itu, ada peringatan agar setiap orang tidak boleh melakukan kecurangan antar sesama. Allah dengan tegas melarang praktek tersebut dengan lepas tangan, tidak lagi ikut dalam membantu usahanya. Di dalam Al-Qur'an juga disampaikan perintah untuk saling tolong menolong dalam kebaikan. Kerjasama dalam berbisnis juga bagian dari saling tolong menolong. Saling mendapatkan keuntungan dan memberikan keuntungan kepada yang lain. Seperti yang termaktub dalam firman Allah Swt yang artinya "Dan tolong-menolonglah kamu dalam (mengerjakan) kebajikan dan 
takwa, dan jangan tolong-menolong dalam berbuat dosa dan pelanggaran (QS AlMaidah: 02).

Dalil ini memberikan pengertian adanya anjuran agar manusia saling kerjasama dan tolong menolong. Setiap melakukan suatu bisnis tidak hanya orientasi pada keuntungan semata, akan tetapi harus selalu terpatri dalam diri bahwa tujuan utama dari kerja sama tersebut adalah tolong-menolang dan memberi manfaat kepada sesama karena Allah.

\section{Jual Beli}

Jual beli adalah usaha tukar menukar barang antara dua orang atau lebih dengan jalan melepaskan hak milik atas dasar kerelaan. Kata jual beli semakna dengan kata perdagangan yang dalam kegiatanya melibatkan penjual, pembeli, dan barang yang diperjual belikan. Maka dapat dipahami bahwa kegiatan jual beli merupakan bagian dari kegiatan yang tidak akan pernah hilang selama manusia masih menjalani kehidupan di dunia. Praktek jual beli dalam Islam harus memenuhi rukun dan syarat yang sudah ditetapkan, sehingga tidak merugikan antara satu dengan lainnya.

Menurut Yadi Janwari (2015) bahwa Jumhur ulama telah menetapkan rukun dan syarat jual beli sebagai berikut:

a. Ada yang berakad (penjual dan pembeli)

b. Ada Shighat

c. Ada barang yang diperjualbelikan

d. Ada nilai tukar pengganti barang (harga barang)

Syarat jual beli sesuai dengan rukun jual beli yang dikemukakan di atas. Kasus yang diteliti secara umum transaksi jual beli yang dilakukan sudah memenuhi rukun yang ada. Namun, ada beberapa syarat yang perlu untuk di uraikan sehingga promblematika yang terjadi bisa dianalisa sesuai dengan hukum Islam. 


\section{Akad Wakalah}

Wakalah adalah al-tafwidh (pendelegasian), al hifæ̧̧ (memelihara), al-dhaman (tanggung jawab dan al-kifarat (Penggantian). Pengertiannya demikian karena wakalah merupakan akan pendelegasian/pemberi kepercayaan oleh pihak pertama kepada pihak kedua untuk melakukan sesuatu yang akan dikerjakan. Pihak yang menerima tersebut sebagai wakil. Sedangkan secara terminologi wakalah bermakna mendelegasikan mandat atau menyerahkan sesuatu kepada orang lain sebagai pengganti dirinya untuk menyelesaikan suatu persoalan yang diperbolehkan secara syari'i. (Atang Abdul Hakim, 2011)

Sedangkan Mardani (2015) mengatakan bahwa wakalah pada dasarnya dibagi menjadi dua, yaitu:

a. Wakalah Muqayyadab: pendelegasian terhadap perkerjaan tertentu, dalam hal ini seorang wakil tidak boleh keluar dari wakalah yang ditentukan dan akad wakalah ini bersifat umum tanpa adanya penjelasan yang terperinci.

b. Wakalah Mutlaqab: Pendelegasian secara mutlak, sebagai wakil dalam berbagai pekerjaan maka seorang wakil dapat melaksanakan wakalah secara luas dan wakil tidak dibatasi dengan syarat dan kaidah tertentu.

Akad wakalah dibedakan menjadi dua, yaitu wakalah yang disertai upah/imbalan dan wakalah tanpa imbalan. Namun wakalab jenis pertama ini ada ketentuan ijarah-nya. Artinya, penerima wewenang berkewajiban mengerjakan pekerjaan yang di-limpahkan sampai selesai. Hal ini pernah dilakukan oleh Rasulullah Saw ketika mengutus karyawannya untuk mengambil shadaqah serta memperlakukannya layak-nya karyawan. Sedangkan dalam wakalah jenis kedua berlaku hukum kebiasaan. Artinya, imbalan jika ada, disesuaikan dengan adat kebiasaan dan tidak diberlakukan ijarah (Atang Andul Hakim, 2011).

Pendapat wakalah juga diuraikan dari kalangan ulama Hanafiyah bahwa rukun wakalah adalah ijab dan kabul. Pernyataan dari pemberi mandat disebut ijab sedangkan penerima mandat sebagai qabul. Menurut Yadi Janwari (2015) mayoritas ulama mangatakan bahwa rukun wakalah ada empat:

a. Orang yang mewakilkan (Al-Muwakki), 
b. Orang yang menerima pewakilan ( $A l-W a k i)$,

c. Objek atau pekerjaan yang diwakilkan (Muwakkil bib),

d. Ijab dan kabul (sighab).

Pendapat tentang rukun wakalah dikalangan para ulama berbeda, namun maksud dan tujuannya sama yaitu memberikan pemahaman dan kemudahan kepada kita untuk memperhatikan segala sesuatu yang menjadi suatu pokok yang harus dipenuhi dalam bertransaki. Apabila tidak terpenuhi rukun yang disepakati maka akad itu akan menjadi batal.

Sedangkan syarat wakalah akan dijelaskan sebagai berikut:

a. Orang yang mewakilkan (Al-Muwakkil)

1) Yang memberi kuasa harus mempunyai wewenang untuk mengurusnya;

2) Pemberi kuasa harus memiliki hak, dan tidak boleh selain dari haknya;

3) Mukallaf (sudah cakap hukum).

b. Orang yang diwakilkan (Al-Waki)

1) Memiliki kecakapan hukum;

2) Amanah dalam segala sesuatu yang diperjanjikan

Keberlangsungan akad wakalah bisa berkahir apabila salah satu pihak dari orang yang berakad meninggal dunia atau pekerjaan yang sudah diwakilkan selesai dilakukan. Apabila yang diberi pelimpahan akad tidak cakap hukum dan tidak bisa mengerjakan pekerjaan maka wakalah batal demi hukum.

\section{Penerapan Akad Wakalah dalam Dunia Bisnis}

Dalam pelaksanaan dalam dunia bisnis sudah diatur dalam UU Nomor 21 Tahun 2008 bahwa akad walakah adalah akad pemberi kuasa untuk penitipan uang atau surat berharga, dimana bank mendapatkan kuasa dari yang menitipkan uang untuk mengelola uang atau surat berharga tersebut. Begitu juga fatwa DSN MU yang memberikan pengertian dengan maksud seperti yang diuraikan dalam undang-undang. Dunia per- 
bankan sudah diterapkan dengan baik karena diatur dalam regulasi dan fatwa yang mendukung dalam kegiatannya, akan tetapi penerapan akad wakalah ini juga sudah menjadi suatu kebiasaan di masyarakat dalam hal kaegiatan infrastruktur, khusus pembangun-an rumah tempat tinggal atau kontrakan. Berdasarkan pembagian wakalah di atas, yang menjadi objek penelitian kali ini adalah wakalah bil ujrah.

Perencanaan pembangunan dimasyarakat baik rumah atau tempat bisnis, mempunyai pola yang berbeda dalam perjanjian dengan ahli bangunan (mandor). Dalam kasus yang ditemukan penulis, bahwa pendelegasian dalam pembelanjaan barang ditoko bangunan banyak terjadi penyimpangan dalam proses jual belinya. Dimana mandor yang diberikan amanah memanfaatkan kesempatan untuk mencari keuntungan dari harga yang ditawar kemudian dalam kwitansi pembeliannya tidak ditulis dengan harga beli yang semestinya. Namun diberikan harga yang lebih tinggi. Kasus seperti banyak terjadi dimasyarakat, khususnya di kecamatan margaasih kabupaten bandung.

Berdasarkan rukun dan syarat yang disebutkan maka dalam transaksi ini ada pemberi kuasa, ada penerima kuasa, ada barang/objek yang diwakilkan dan ada akad yang diperjanjikan. Fokus tulisan ini hanya pada proses wakalah dalam hal pembelian barang bangunan yang kemudian dilakukan perubahan pada harga kwitansi yang dibuat oleh pemilik toko bangunan.

Menurut pemilik toko bangunan bahwa transaksi ini sudah biasa dilakukan dan menjadi kebiasaan bagi setiap pemilik toko untuk memberikan harga dan kwitansi yang diminta oleh mandor (yang diberi kuasa). Dalam jual beli keuntungan yang didapatkan adalah sesuatu yang sangat lumrah, namun dalam hal pemberian kuasa kemudian mencari keuntungan dengan merubahan kwitansi yang dilaporkan adalah perkara yang perlu diteliti lebih lanjut.

\section{Metode Penelitian}

Adapun metode dalam penelitian ini diperoleh melalui penelitian lapangan (field reseach) dan juga literatur yang dipadukan sehingga dapat ditarik kesimpulan secara deduktif berdasarkan kaidah-kaidah serta syarat dan ketentuan dari pelaksanaan akad jual beli 
dengan sistem wakalah. Adapun teknik pengumpulan data melalui wawancara kepada orang terkait dan juga dokumentasi berupa data atau media cetak lainnya yang bisa mendukung dalam penelitian ini.

\section{Hasil Penelitian dan Pembahasan}

Konsep jual beli dengan sistem wakalah merupakan suatu pelimpahan pekerjakan kepada orang lain karena sebab waktu dan kemampuan dalam suatu pekerjaan yang tidak bisa dilakukan sendiri. Seperti pembangunan rumah yang dilimpahkan kepada orang lain. Praktek wakalah ini sudah menjadi kebiasaan masyarakat Cigondewah Hilir kabupaten Bandung. Pemilik Rumah memberikan kewenagan kepada pemborong sebagai orang yang diwakilkan dengan sistem upah atau ujroh dari pekerjaan yang telah disepakati.

Kasus yang terjadi dalam jual beli ini, misalnya kesepakatan harga yang ditawakan Rp. 25.000 pada item tertentu kepada toko bangunan, namun dalam kwitansi pembayaran bisa terjadi perubahan menjadi Rp. 30.000 atas permintaan pemborong agar mendapatkan keuntungan. Proyek pembangunan yang sudah diserahkan secara keseluruhan kepada pemborong, namun bahan baku masih menjadi tanggungjawab pemilik rumah untuk membayarnya.

Dilihat dari hukum kebiasaan, maka bisa menjadi boleh karena pemilik dan pembuat bangunan sama-sama sepakat dalam menjalankan akadnya dan menjadi kebiasaan bagi masyarakat setempat. Apabila dilihat dari rukun dan syarat jual beli dengan sistem wakalah, maka akad ini menjadi batal, karena tidak ada kejujuran dari wakil, ada unsur penipuan, sehigga menimbulkan kecurigaan yang berdampak pada kerugian bagi pemilik bangunan. Perjanjian akad wakalah diperbolehkan mengambil keuntungan dari transaksi tersebut apabila ada transparansi serta syarat dan ketentuan diperjanjikan pada awal akad, misalnya segala sesuatu diserahkan kepada pemborong bangunan dalam pembelian barang bangunan dengan ketentuan keuntungan diserahkan sepenuhnya oleh pemilik bangunan. 


\section{E. Penutup}

Berdasarkan kajian yang telah diuraikan sebelumnya maka dapat disimpulkan bahwa jual beli bahan bangunan antara al-muwakkil dan al-wakil dimana dalam prakteknya alwakil menyertakan kwitansi sebagai bukti pembiayaan terhadap al-muwakkil dapat ditinjau dari dua sisi, yaitu jika dilihat dari kebiasaan, maka bisa menjadi boleh karena almuwakkil dan al-wakil sama-sama telah diikat dalam suatu kesepakatan. Namun, jika dilihat dari sisi rukun dan syarat jual beli berdasarkan sistem wakalah, maka akad ini menjadi batal, karena memiliki potensi penyalahgunaan dari al-wakil, hal ini termasuk unsur penipuan, sehingga menimbulkan kecurigaan yang berdampak pada kerugian bagi al-muwakkil. Dalam perjanjian akad wakalah diperbolehkan mengambil keuntungan dari suatu transaksi apabila ada transparansi serta syarat dan ketentuan diperjanjikan pada saat awal akad.

Saran yang dapat diberikan oleh penulis terkait ini hendaknya ada transparansi antara pihak pemborong dengan pemilik bangunan baik dalam estimasi pembiayaan maupun dalam pelaporan dalam bentuk kwitansi sehingga akan tumbuh sifat saling percaya antara pihak satu dengan lainnya. Sehingga dampaknya ke depan bisa menguntungkan kedua belah pihak baik dari sisi pemborong karena dengan diketahuinya sifat-sifat kejujuran pemborong akan memunculkan kepercayaan serta daya tarik pelanggan lainnya, begitu pula dari sisi pelanggan atau pemilik bangunan yang merasa puas dan terkesan.

\section{DAFTAR PUSTAKA}

Akbar, P.S. 2011. Metodelogi Penelitian Sosial, edisi ke-2. Jakarta: BumiAksara

Ash-Shawi dan Al-Mushlih. 2014. Fikih Ekonomi Islam, Terjemahan Abu Umar. Jakarta: Darul Hak

Dasuqi, A.H, dkk.,1990. Al-Qur'an Al-Karim Wa Tarjamatu Ma'anibi Ila Al-Lughoti AlIndunisiyyah. Jakarta: Mujamma' Al-Malik Fahd Li Thiba'at Al-Mush-haf AsySyarif Madinah Al-Munawwarah

Hakim, A.A. 2011. Fiqih Perbankan Syariah, Transformasi Fiqih Muamalah ke dalam Peraturan Perundang-Undangan. Bandung: Reflika Aditama

Janwari, Y. 2015. Fiqib Lembaga Keuangan Syariah. Bandung: Remaja Rosda Karya

Mardani. 2014. Hukum Bisnis Syariah. Jakarta: Pustaka Kencana

Sugiyono. 2012. Metode Penelitian Kuantitatif, Kualitatif dan RひD. Bandung: Alfaberta

Suhendi, H. 2016. Fiqh Muamalah. Jakarta: Rajawali Pers 